\title{
Are Accounting Softwares Replacing Accountants? Perspectives of Professional Accountants in Ghana
}

\author{
Isaac Luke Agonbire Atugeba $^{1 *} \quad$ Boadu Ayeboafo $^{2} \quad$ Dawuda Abudu $^{1}$ \\ 1.Department of Accounting and Finance, Bolgatanga Technical University, P. O. Box 767, Bolgatanga, Ghana \\ 2.Department of Accountancy and Accounting Information System, Kumasi Technical University, \\ P. O. Box 854, Kumasi, Ghana
}

\begin{abstract}
The integration of accounting software in modern-day accounting duties has called for an evaluation of the impact of these applications on the accountancy profession in Ghana. Thus, the purpose of this study is to assess the impact of accounting software on the accountancy profession. The study adopted a descriptive research design with a target population of 4,834 chartered accountants in Ghana. A sample size of 369 professional accountants was selected for the research; however, 235 accountants responded to the questionnaire representing a 63.7 percent response rate. Descriptive statistics including Kendall's coefficient were used to analyze the study results. The findings of the research indicate that the incorporation of accounting software is not a threat to the accountancy profession (in terms of job losses and demotion) and that the role of accountants is still relevant in the working environment. However, the study established that most professional accountants have become outmoded as a result of the incorporation of accounting software in the accountancy profession. The study also finds that accounting professionals with accounting software backgrounds are categories of graduates likely to gain employment in current accounting practice. The study recommends that professional bodies such as ICAG and other business institutions should include accounting software education in their curriculum. This would help graduates of these accountancy bodies to be more relevant in the job market, which employers will gradually be in search for in the future.
\end{abstract}

Keywords: Accounting Software, Professional Accountants, Ghana

DOI: $10.7176 /$ RJFA/12-18-02

Publication date:September $30^{\text {th }} 2021$

\section{Introduction}

Accounting has been the most stable discipline in management and assumes a significant part in the accomplishment or failure of business organizations (Shiraj, 2015). However, modern accounting has seen changes but the concept is still grounded on the framework created by an Italian monk Luca Pacioli over centuries in the past (DeSantis, 2010). In keeping up accounting data, organizations are concerned principally with the procedures for recording transactions, performing internal audit reviews, and reporting financial data to managers and other interested parties related to the organization (Amanamah, Morrison \& Asiedu, 2016; Lim, 2013; Ghasemi, Shafeiepour, Aslani \& Barvayeh, 2011). The accounting system reveals the profit or loss, and the worth and nature of the organization's resources, obligations, and equity for a given period.

Manual accounting systems have been the ancient form of recording business transactions with the capability of reporting accounting information to business owners. As per Magloff (2013), manual system of keeping financial records have been seen to be the easiest, simple and less expensive means of maintaining accounting information. Nonetheless, the records in paper-based bookkeeping frameworks are inclined to harm by water, fire, and various perils. Likewise, when there are numerous transactions to record in a business (Amanamah et al, 2016; Ghasemi et al, 2011); there is always a challenge with the use of manual systems. Thus, the volume of transactions to be recorded and maintained at a time can be a detriment of manual bookkeeping frameworks.

The extensive use of personal computers (PCs) has efficiently offered certain ease, swiftness, and accuracy to how business organizations are managed. That is, starting from simple entering of figures to scrutinizing of multifaceted accounting information (Machera \& Machera, 2017; Daru, 2016; Birungi, 2000). Thus, a computerized accounting system is a type of accounting system that involves the use of a computer hardware and software to manage accounts and perform accounting responsibilities (Daru, 2016).

Contemporary accounting work has evolved from figure crunching by accountants' knowledge and skills to a computerized form of recording and analysing financial information. This has, however, brought some discomfort to the accounting profession. Nagarajah (2016) opined that automation is frightening a number of jobs with obsolescence, and accountants are the most affected. According to Frey and Osborne (2014) (as cited in Nagarajah, 2016), 47 percent of job categories are open to computerization within the last three decades. Accountants and auditors are the second highest in terms of job loss risk, just after telemarketers. On the word of Poston (2014), it is not true yet, but a computer-based accounting framework is endeavoured to eradicate certified accountants. Unexpectedly, certified accountants are instrumental in consulting with programming 
engineers to make the very innovation that will supplant them.

In Ghana, a number of accounting works in businesses are done by non-professional accountants who are typically former students of business studies with the Royal Society of Accountancy (RSA), Diploma in Business Studies (DBS), Higher National Diploma in Accounting, and first-degree qualification in accounting. For qualified accountants, they are typically found in larger companies and some in multinational companies. For Zotorvie (2016), to become a qualified accountant in Ghana, one needs to pass or be exempted from a sequence of professional exams and undergo a period of relevant practical training in the field of accounting. The accounting body which trains professional accountants in Ghana is the Institute of Charted Accountants, Ghana (ICAG). Other foreign professional bodies whose qualifications are acceptable in Ghana include the Association of Chartered Certified Accountants (ACCA), Chartered Institute of Management Accountants (CIMA), and Chartered Institute of Public Finance and Accountancy (CIPFA).

Considerably, there have been a number of studies that have delved into the benefits and possible challenges related to the use of computerized accounting systems in businesses (see Daru, 2016; Kabir, Rahman, Yunus \& Chowdhury, 2015; Tijani \& Mohammed, 2013; Ghasemi et al, 2011). Notwithstanding the relevance and limitations of accounting software, it is alarming to note that no attempts have been made by any researcher to look at the implications of accounting software invention to "the person" at the helm of performing accounting responsibilities. The aim of the study is, thus, to find out whether the integration of accounting software in modern-day accounting duties is a blessing or a threat to the accountancy profession in Ghana.

In the next section, we provide evidence of related work which informs the present research. The third section presents the research design and data analysis method, while Section four presents the results of our study. Finally, conclusion and policy implications are presented in Sections five accordingly.

\section{Literature Review}

\subsection{The Accounting Profession in Ghana}

Ghana was acquainted with the British educational framework as a former colony. During the colonial time, the administrative staff, including bookkeepers, for most organizations set up in the country by British financial investors was, by and large, brought from the UK. Around then, an individual could become an expert bookkeeper simply by admission to one of the British professional accounting bodies. Just a few local individuals who could bear the expense of instruction and training abroad continued to England to get proficient capabilities.

A milestone for the improvement of the accounting profession in British West Africa was the foundation of the Association of Accountants in the Gold Coast (presently Ghana) in 1954. Individuals from this body were mostly Ghanaian graduates in accounting who dominated in both the accounting education and reasonable training by British professional accounting bodies. They went about as accountants and consultants to governments that steered affairs of Ghana on the issue of bookkeeping and setting accounting laws and guidelines (Mbawuni, 2015). This body was changed to the Institute of Chartered Accountants, Ghana (ICAG) in 1963 by an Act of Parliament, Act 170.

The ICAG is the sole body in Ghana with the right to grant the Chartered Accountant title and with the right to control the accounting profession in Ghana (Zotorvie, 2016). The Institute has indistinguishable rules as the UK accounting bodies. That is, ICA (England and Wales) and ICA (Scotland) as far as comparable assessments and training structures as it is in Britain (Wijewardena \& Yapa, 1998).

In 1978, ICA (England and Wales) gave ICAG full proficient autonomy and opportunity in the wake of being persuaded of ICAG's guidelines of assessment and participation capabilities to be acceptable and that ICAG could deal with its issues. There are currently two classifications of enrolment; (a) the individuals who qualify by taking and passing the examinations of the Institute and (b) the individuals who are conceded by ideals of their participation of other accounting bodies so regarded by the Council. Under group (b) is an enormous number of Association of Certified Chartered Accountants (ACCA), Institute of Chartered Accountants England and Wales (ICAEW), Chartered Institute of Management Accountants (CIMA), and Certified Public Accountants (CPA). ICAG is additionally a member of territorial and global accounting proficient bodies like the Association of Accountancy Bodies in West Africa (ABWA), the International Federation of Accountants (IFAC), and the Pan-African Federation of Accountants (PAFA).

\subsection{Accountants and their Role in Businesses}

An accountant is a professional who performs monetary tasks such as collecting, documenting, analysing, and presenting financial data to interested parties (Davis, 2015; Isiavwe, 2016). Within an organization's operations, an accountant often performs a variety of managerial and administrative tasks. Financial data gathering, data input, and report preparation may be part of an accountant's job description in a small business. An accountant can serve as an adviser and financial analyst for medium- to large-sized businesses, and can communicate the company's financial data to both internal and external stakeholders. Outsiders, such as sellers, clients, and 
financial institutions, are sometimes typically managed by the accountant (Kamyabi \& Devi, 2011).

Ray (2015) accepts that the bookkeeper at an organization can serve numerous roles, from regulating the preparation of all financial reports identified with the organization to carrying out monetary techniques made by the board or settling on investment choices for the firm. As a chief accountant, he/she may sit in the upper supervisory team to have an essential influence in making long-haul objectives. In a bigger business, the accountant may likewise control a group of financial experts. As indicated by Isiavwe (2016), despite the fact that the management is answerable for the monetary data delivered by the organization, accountants are on the cutting edge of defending the uprightness of monetary reports. Consequently, the accountant is a significant staff to the organization since the individual in question has the key abilities needed to communicate in the language of business.

Krell (2008) expressed that proficient bookkeepers in business assume vital parts in recognizing and tending to extraordinary difficulties confronting average-sized ventures in strategic management, corporate administration, risk management, internal control, financial reporting, and accounting. Jui and Wong (2017) expressed that the bookkeeping experts in the business help with corporate strategy, give advice, and assist organizations with decreasing expenses, and moderate risks. As the board, skilled accountants in the business stand in place in the interest of the proprietors of the organization. Their responsibilities often include managing the organization (for example, approving yearly financial goals and reporting on the organization's performance to stakeholders); choosing the CEO; and determining management's salary.

\subsection{Accounting Software}

The decision to use a manual or digital accounting system is made by the company itself (Amanamah et al, 2016). Computerization of accounting duties is the act of converting manual functions into automated systems via software (Dabor, Aggreh \& Aneru, 2016). Daru (2016) characterized an accounting program as a kind of program that records and processes accounting transactions inside functional modules, for example, creditor liabilities, debt claims, payroll, and trial balance. The accounting program functions as a bookkeeping data framework. They are additionally utilized by organizations to oversee accounts and perform bookkeeping activities. The accounting software program has not upset the act of bookkeeping but has brought about new sorts of bookkeeping applications for organizations (Burdick, 2010).

Because of the rapid advancement of technology, many businesses prefer to use accounting software to manage financial transactions rather than depending on a manual approach of bookkeeping (Mtetwa, 2010). As data innovation has progressed, accounting software has been developed to assist in the production of meaningful financial reports for management and other stakeholders to use in making decisions. Burdick (2010) emphasizes the importance of accounting software for a company to be competitive in today's business environment. Accounting software allows a company to keep track of its financial health. In most cases, it enables the business to enter all expenses and income in the system in real-time (Daru, 2016). Businesses of all sizes make use of accounting software and there is still some software that is under development. As per Daru (2016), the most commonly used accounting software include; Quick Books, Sage Pastel accounting, and Tally ERP 9.

\subsection{Empirical Literature}

Accounting software, according to Daru (2016), is primarily used to keep track of cash flows, processes, document transactions, make computations, and generate reports. Accounting software, on the other hand, helps improve firm operations, profitability, efficiency, and cost reduction in the long run. Kabir et al (2015) researched to find out whether private universities in Bangladesh are practicing automated accounting processes through the applications of software. On the perceptions of accountants about the application of accounting software, all the respondents sampled for the study gave an opinion in favour of accounting software that it is faster to apply in their accounting job. This notwithstanding, the research findings of Kabir et al revealed that the main reasons why accountants still rely on manual accounting systems are as a result of management's and employees' reluctance to implement the system.

Machera and Machera (2017) outlined the accompanying advantages of accounting software in business; simple to reconcile stock balances, simple upkeep of asset registers, provision for graphs and monetary proportions, furnishes the business with monetary insight, upgrades speed for section handling, and upgrades fulfilment and exactness. Birungi (2000) is of the assessment that utilizing PC bookkeeping programming does not just accelerate bookkeeping responsibilities, yet additionally guarantees precise data conveyance than manual bookkeeping. However, according to Magloff (2013), using an electronic bookkeeping system has with its own set of concerns, such as the necessity to protect against data loss due to influence dissatisfaction or infections, as well as the risk of programmers stealing data.

Amidu (2013) led an investigation to look at e-bookkeeping practices among Ghanaian SMEs. The examination uncovered that practically all the SMEs inspected append a ton of significance to monetary data by 
utilizing in any event degree holders and Chartered Accountants to deal with their bookkeeping data. The examination likewise showed that most of the organizations set up bookkeeping programs to produce monetary data. This tends to diminish cost, upgrade administrative works, and give adequate room to store information, and process data for the executives' choices in a timely way. Regarding usefulness, the consequences of the study showed that practically all the SMEs utilize the software for accounts receivables works just as records payables, stock management, payroll, fixed assets management, and automated bookkeeping framework management.

An examination led by Adesoju (2014) on inside control frameworks in a mechanized bookkeeping climate revealed that the approach of modernized bookkeeping has assisted with improving adequacy in processing transactions. Similar research conducted by Daoud and Triki (2013) established that the utilization of bookkeeping programs can possibly impact business performance.

In the midst of the few advantages of bookkeeping programs that can be recorded, they are likewise plagued with difficulties. The hindrances to carrying out mechanized bookkeeping programming include the absence of time, the proprietor-directors see that the modernized bookkeeping program is expensive, the discernment that the innovation isn't fit the concept of the business, and the lack of IT talent (Anaeli, 2018; Head, 2000). Besides, there is a danger of inappropriate human mediation with PC programs and computer documents. Representatives in the association may temper with the computer programs and PC-based records with the end goal of purposely misrepresenting bookkeeping data. This may bring about contortion of data that would be for decision making.

\section{Methodology}

\subsection{Research Design}

The research explored the application of accounting softwares in performing accounting responsibilities in various organizations (both public and private) in Ghana. In that regard, the research design considered most suitable in this study is descriptive research approach. A descriptive research approach systematically explains the phenomenon connected with the subject and allows the researchers to obtain direct information from participants of the study (Saunders, Lewis \& Thornhill, 2009; Kothari, 2004).

\subsection{Study Area}

The research was conducted in Ghana, a West Africa country. The nation occupies a surface area of 239,567 $\mathrm{km} 2$ and has an estimated population of over 30 million people across its 16 regions.

\subsection{Population and Sample}

The population includes all 4,834 chartered accountants in Ghana (ICAG Annual Report, 2019). The study used a convenient sampling technique in the sample selection. This sampling method was used to select 369 chartered accountants in Ghana. The sample size was chosen from a target population of 4,834 potential respondents by the utilization of Taro Yamane's formula of sampling (Yamane, 1967). The equation expresses that;

$$
\mathrm{n}=\frac{\mathrm{N}}{1+\mathrm{N}(\mathrm{e})^{2}}
$$

Where $\mathrm{n}$ is the sample size; $\mathrm{N}$ is the total population; and e stands for the level of sampling error (usually 0.10 , 0.05 , and 0.01 acceptable error). The study therefore used a sampling error of $5 \%$ to decide the sample size of the research.

$$
\mathrm{n}=\frac{4,834}{1+4,834(0.05)^{2}}=369.43=369
$$

\subsection{Research Instrument}

The researchers used a questionnaire for the study. The questionnaire is divided into two sections (A and B). Section "A" contained questions demanding information about the demographics profile of the participants. Section "B" had closed-ended questions looking for information about the usage of accounting software in performing accounting duties. The questionnaire also contained Likert-scale questions to measure the extent of agreement or disagreement with the benefits as well as the threats of using accounting software in accounting duties. The reliability of this study was tested by Cronbach Alpha. The reliability of the 16-item scale was 0.65 , way above the recommended 0.5 level (Hatcher, 1994; Santos, 1999).

\subsection{Data Collection and Analysis}

The questionnaires were designed with a Google Form and administered on the various recognized District Societies WhatsApp platforms across the 16 regions of Ghana. These platforms were carefully chosen because they are perceived as the most popular avenues of getting the respondents to take part in the study. At all events, consent was sought from presidents of the various District Societies before sharing the Google Form (questionnaire) Link to the participants. Involvement in the study was voluntary and respondents were guaranteed information privacy. The period of data collection was within 50 days. The data was edited to 
identify and address potential mistakes and exclusions that occurred when answering the questionnaire. This was to ensure consistency across respondents before coding. The Statistical Package for Social Sciences (SPSS) version 20 was employed to capture and run the analysis. The study also adopted the use of tables, statistical measurement of simple percentage scores and descriptive content approach in analysing the data collected for this study. Specifically, the results were analysed using descriptive statistics including Kendall's coefficient.

\section{Results}

\subsection{Respondents' Profile}

The research sampled 369 professional accountants across the 16 regions of Ghana. However, 235 accountants responded to the questionnaire representing a 63.7 percent response rate. Respondents' gender, academic qualification, working experience as well as the sector of the economy they work were considered as necessary for the study.

Table 1: Demographic Profile of Respondents

\begin{tabular}{|l|c|c|}
\hline Profile & Frequency & Percentage \\
\hline Gender & & 8.5 \\
\hline Female & 20 & 91.5 \\
\hline Male & 215 & 4.3 \\
\hline Academic qualification & 10 & 21.3 \\
\hline HND & 50 & 74.5 \\
\hline $1^{\text {st }}$ degree & 175 & \\
\hline $2^{\text {nd }}$ degree & & 4.3 \\
\hline Working experience & 10 & 21.3 \\
\hline Less than a year & 50 & 36.2 \\
\hline $1-5$ years & 85 & 23.4 \\
\hline $6-10$ years & 55 & 14.9 \\
\hline $11-15$ years & 35 & \\
\hline 16 years and above & & \\
\hline Sector of the economy & 115 & \\
\hline Public & 120 & 58.9 \\
\hline Private & & \\
\hline
\end{tabular}

Total Respondents $=\mathbf{2 3 5}$

As indicated in Table 1, the study shows most professional accountants in Ghana are males (91.5 percent) with the highest academic qualification being second degree ( 74.5 percent). The research further shows that most of the respondents have been working in their respective organizations for more than five years ( 74.5 percent) with a majority of them employed in the private sector (51.1 percent). This indicates that the respondents in the survey had a solid educational foundation as well as the appropriate work experience to comprehend the study's goal and deliver accurate responses.

\subsection{Most Used Accounting Software in Ghana}

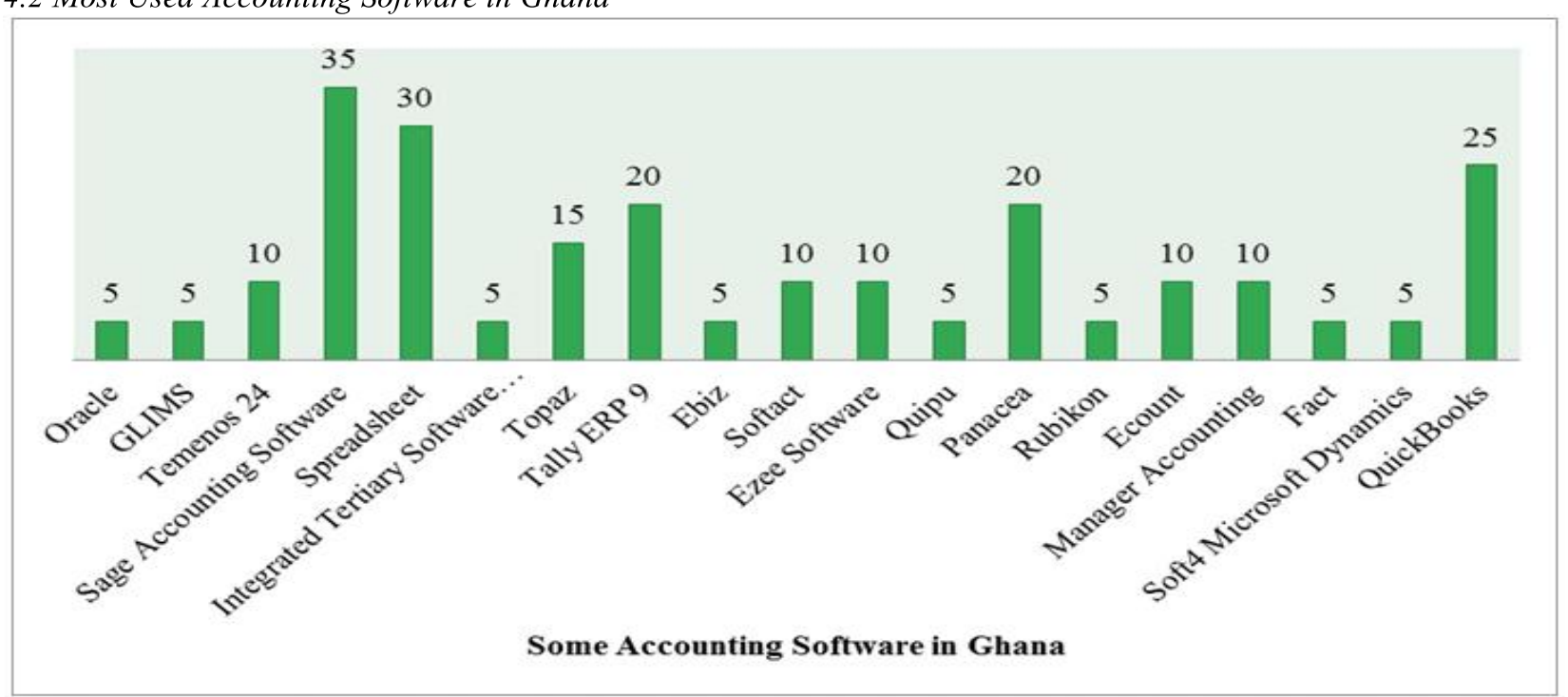

Figure 1: Most Used Accounting Software in Ghana 
Figure 1 shows that there are many accounting software being used in various organizations (both private and public) in Ghana. This notwithstanding the modal accounting software used by most businesses is Sage Accounting Software (35 responses), followed by QuickBooks ( 25 responses). Tally ERP 9 and Panacea had 20 responses each. The study further established that Microsoft Excel (without pre-automated features) is highlighted as a great tool for professional accountants with 30 respondents professing to be using it.

\subsection{Benefits of Accounting Softwares in Performing Accounting Duties}

In assessing the benefits of accounting softwares in performing accounting duties, the respondents were require to indicate their level of agreement or disagreement with respect to some items on benefits of accounting softwares usage in businesses.

Table 2: Benefits of Accounting Softwares in Performing Accounting Duties

\begin{tabular}{|c|c|c|c|c|c|c|c|}
\hline & \multicolumn{2}{|c|}{ Agreed } & \multicolumn{2}{|c|}{ Disagree } & \multirow[b]{2}{*}{$\begin{array}{l}\text { Mean } \\
\text { Rank }\end{array}$} & \multirow[b]{2}{*}{$\begin{array}{c}\text { Rank } \\
\text { position }\end{array}$} & \multirow[b]{2}{*}{$\begin{array}{c}\text { Test } \\
\text { Statistics }\end{array}$} \\
\hline Benefits & Freq. & Percent & Freq. & Percent & & & \\
\hline $\begin{array}{l}\text { It is easy to modify data in } \\
\text { accounting software }\end{array}$ & 185 & 78.7 & 50 & 21.3 & 2.68 & $3^{\text {rd }}$ & $n=235$ \\
\hline $\begin{array}{l}\text { Accounting software help in easy } \\
\text { and timely generation of financial } \\
\text { statements }\end{array}$ & 230 & 97.9 & 5 & 2.1 & 3.16 & $1^{\text {st }}$ & $\begin{array}{l}\text { Kendall's W } \\
\quad=0.104 \\
\text { Chi-Square }=\end{array}$ \\
\hline $\begin{array}{l}\text { Accounting software has high } \\
\text { storage capacity }\end{array}$ & 230 & 97.9 & 5 & 2.1 & 3.16 & $1^{\text {st }}$ & $\begin{array}{c}97.297 \\
\mathrm{df}=4\end{array}$ \\
\hline $\begin{array}{l}\text { Accounting software has back up } \\
\text { facility }\end{array}$ & 230 & 97.9 & 5 & 2.1 & 3.16 & $1^{\text {st }}$ & $\begin{array}{l}\text { Asymp. Sig. } \\
\quad=0.000\end{array}$ \\
\hline $\begin{array}{l}\text { Accounting software aid in easy } \\
\text { filing of taxes }\end{array}$ & 200 & 85.1 & 35 & 14.9 & 2.84 & $2^{\text {nd }}$ & \\
\hline
\end{tabular}

As indicated in Table 2, the research reveals that out of 235 total respondents, 185 respondents representing 78.7 percent agreed that "It is easy to modify data in accounting software" while 50 respondents representing 21.3 percent disagreed. This shows that majority of accountants considered the easy modification feature of accounting softwares as a significant benefits of accounting softwares.

The benefits of accounting software concerning; easy and timely generation of financial statements, high storage capacity, and capability of backing up data were considered to be paramount. Specifically, 238 respondents each representing 97.9 percent agreed that accounting software is beneficial while five respondents each representing 2.1 percent disagreed.

Finally, the study reveal that out of 235 total respondents, 200 respondents representing 85.1 percent agreed that "Accounting software aid in easy computation of taxes" while 35 respondents representing 14.9 percent disagreed. This shows that the majority of accountants consider the easy computation of taxes features of accounting software as a benefit of accounting software.

The study further tested for the most beneficial aspect of accounting software by using Kendall's coefficient of concordance (W). From Table 2, the top three benefits of accounting software include: easy and timely generation of financial statements, high storage capacity, and capability of backing up information. These benefits occupied the first position accordingly. Meanwhile, easy computation of taxes, and easy to modification of information were the least beneficial aspect of accounting software, by trailing in the $2^{\text {nd }}$ and $3^{\text {rd }}$ positions, respectively.

The coefficient of concordance of 0.104 with 4 degrees of freedom at 99 percent confidence level, implies that 10.8 percent of agreement in the level of rankings by the respondents. This level of rankings is statistically significant as the significance value is 0.000 , less than the compared alpha value of 0.05 . Thus, generally, easy and timely generation of financial statements, high storage capacity and ability of backing up information are the major benefits of using accounting softwares among professional accountants in Ghana.

4.4 Limitations in the Usage of Accounting Softwares

In evaluating the limitations in the use of accounting software, the respondents were also required to indicate their level of agreement or disagreement concerning some items on precincts of accounting software. 
Table 3: Limitations in the Usage of Accounting Softwares

\begin{tabular}{|c|c|c|c|c|c|c|c|}
\hline & \multicolumn{2}{|c|}{ Agreed } & \multicolumn{2}{|c|}{ Disagreed } & & & \\
\hline Limitations & Freq. & Percent & Freq. & Percent & $\begin{array}{l}\text { Mean } \\
\text { Rank }\end{array}$ & $\begin{array}{c}\text { Rank } \\
\text { position }\end{array}$ & $\begin{array}{c}\text { Test } \\
\text { Statistics }\end{array}$ \\
\hline $\begin{array}{l}\text { The use of accounting software } \\
\text { needs special training }\end{array}$ & 230 & 97.9 & 5 & 2.1 & 3.78 & $1^{\text {st }}$ & $n=235$ \\
\hline $\begin{array}{l}\text { Accounting software does not } \\
\text { interpret accounting information } \\
\text { independently }\end{array}$ & 210 & 89.4 & 25 & 10.6 & 3.52 & $3^{\text {rd }}$ & $\begin{array}{l}\text { Kendall's W } \\
\quad=0.082 \\
\text { Chi-Square }\end{array}$ \\
\hline $\begin{array}{l}\text { Possibility of data lost through } \\
\text { viruses }\end{array}$ & 175 & 74.5 & 60 & 25.5 & 3.07 & $5^{\text {th }}$ & $\begin{array}{c}=96.296 \\
\text { df }=5\end{array}$ \\
\hline It is very expensive to implement & 205 & 87.2 & 30 & 12.8 & 3.46 & $4^{\text {th }}$ & Asymp. Sig. \\
\hline $\begin{array}{l}\text { It requires high level of security } \\
\text { settings }\end{array}$ & 220 & 93.6 & 15 & 6.4 & 3.65 & $2^{\text {nd }}$ & $=0.000$ \\
\hline $\begin{array}{l}\text { Accounting standards are not } \\
\text { incorporated in most accounting } \\
\text { systems }\end{array}$ & 210 & 89.4 & 25 & 10.6 & 3.52 & $3^{\text {rd }}$ & \\
\hline
\end{tabular}

As pointed out in Table 3, the study reveals that out of 235 total respondents, 230 respondents representing 97.9 percent agreed that "The use of accounting software needs special training" with just five respondents representing 2.1 percent disagreeing. This shows that the majority of accountants considered special training on the usage of accounting software as a drawback to accounting practice.

The limitation of data security requirement was deliberated to be another limitation in the usage of accounting. Specifically, 220 respondents representing 93.6 percent agreed while 15 respondents representing 6.4 percent disagreed. The study further considers lack of independent interpretation of accounting information and non-incorporation of most accounting standards in most accounting systems as significant limitations of accounting software. Specifically, 210 respondents each representing 89.4 percent agreed while 25 respondents each representing 10.6 percent disagreed, accordingly.

For accounting software being very expensive to implement, the following views were recorded; 205 respondents representing 87.2 percent agreed 30 respondents representing 12.8 percent disagreed. Finally, the study revealed that out of 235 total respondents, 175 respondents representing 74.5 percent agreed that there is a possibility of data lost through viruses while 60 respondents representing 25.5 percent disagreed. This shows that the majority of accountants consider the loss of data through virus infection as a limitation of accounting software.

The research additionally tested for the most limiting factors of accounting software by means of Kendall's coefficient of concordance (W). From Table 3, the top four limitations of accounting software include: the need for special training, high level of security settings, lack of independent interpretation of accounting information, and non-incorporation of most accounting standards in most accounting systems. These limitations occupied the $1^{\text {st }}, 2^{\text {nd }}$ and $3^{\text {rd }}$ positions, respectively. Meanwhile, accounting software being very expensive to implement, and possibility of information lost through viruses were the least limitations of accounting software, by trailing in the $4^{\text {th }}$ and $5^{\text {th }}$ positions, respectively.

With a coefficient of concordance of 0.082 and 5 degrees of freedom at a confidence level of 99 percent, the respondents agree on 8.2 percent of the time. Because the significance value is 0.000 , which is less than the significance limit of 0.05 , this level of ranks is statistically significant. Therefore, largely, the need for special training, high level of security settings, lack of independent interpretation of accounting information, and nonincorporation of most accounting standards in most accounting systems are the major limitations of using accounting softwares among professional accountants in Ghana.

\subsection{Impact of Accounting Softwares to Accountants'Job}

In assessing the impact of using accounting software on accountants' job positions, the respondents were necessitated to point out their level of agreement or divergence concerning the effect on job loss, demotion, and obsolescence. 
Table 4: Impact of Accounting Softwares to Accountants' Job

\begin{tabular}{|c|c|c|c|c|c|c|c|}
\hline & \multicolumn{2}{|c|}{ Agreed } & \multicolumn{2}{|c|}{ Disagreed } & & & \\
\hline Threats & Freq. & Percent & Freq. & Percent & $\begin{array}{l}\text { Mean } \\
\text { Rank }\end{array}$ & $\begin{array}{c}\text { Rank } \\
\text { position }\end{array}$ & Test Statistics \\
\hline Job loss & 145 & 61.7 & 90 & 38.3 & 2.00 & $2^{\text {nd }}$ & $n=235$ \\
\hline Demotion & 115 & 48.9 & 120 & 51.1 & 1.81 & $3^{\text {rd }}$ & Kendall's W $=0.104$ \\
\hline Obsolescence & 175 & 74.5 & 60 & 25.5 & 2.19 & $1^{\text {st }}$ & $\begin{array}{c}\text { Chi-Square }=49.091 \\
\text { df }=2 \\
\text { Asymp. Sig. }=0.000\end{array}$ \\
\hline
\end{tabular}

As indicated in Table 4, most of the respondents of 74.5 percent indicated that accounting software has made them archaic in their job while 25.5 percent of the respondents disagreed. Also, 61.7 percent of the respondents point out job loss as a major impact of accounting software while 35.3 percent held a contrarily view. With respect to demotion in most accounting jobs as a result of accounting software, 48.9 percent of the respondents agreed while 51.1 percent disagreed.

The research further verified for the most adverse effect of accounting software by means of Kendall's coefficient of concordance (W). From Table 4, the issue of obsolescence was top, followed by job loss, and the least being demotion. The coefficient of concordance of 0.104 with 2 degrees of freedom at 99 percent confidence level, implies that 10.4 percent of agreement in the level of rankings by the respondents. This level of rankings is statistically significant as the significance value is 0.000 , less than the significance level of 0.05 . This means that the problem of obsolesces as a result of the integration of accounting software is in the short run an issues to most professionals in the accounting field. However, the problem of job losses and demotions is likely to hit the accountancy profession in the medium to long term.

\subsection{Graduates Likely to Gain Employment in Current Accounting Practice}

Table 5: Graduates Likely to Gain Employment in Current Accounting Practice

\begin{tabular}{|l|c|c|}
\hline Category & Frequency & Percentage \\
\hline Accounting Professionals with Accounting Software background & 235 & 100.0 \\
\hline Accounting Professionals without Accounting Software background & 0 & 0.0 \\
\hline Total & $\mathbf{2 3 5}$ & $\mathbf{1 0 0 . 0}$ \\
\hline
\end{tabular}

In assessing the category of graduates likely to gain employment in current accounting practice, it was indicated in Table 5 that accounting professionals with accounting software background are preferable in the job market.

\section{Conclusion and Policy Implications}

The integration of accounting software in modern-day accounting duties has called for a study on the impact of these applications on the accountancy profession in Ghana. First, the study revealed that the benefits of accounting software in performing accounting duties among others include; easy and timely generation of financial statements, high storage capacity, and capability of taking backing up. The finding of this study is consistent with prior studies conducted by Machera and Machera (2017), Daru (2016), Kabir et al (2015), and Birungi (2000). The research further established that, though accounting software comes with tremendous benefits, certain factors such as the need for special training, high data security requirement, lack of independent interpretation of accounting information and non-incorporation of most accounting standards in most accounting systems are some of the major limitations of accounting software. Interestingly, the research established that job loss and demotion are not the major impacts of accounting software on professional accountants in Ghana as argued by Frey and Osborne (2014) and Poston (2014). Nagarajah (2016) further contends that humans are irreplaceable in the work environment especially in advisory services and strategic decision makings. This notwithstanding, the study established that most professional accountants have become outmoded as a result of accounting software. The study further finds that accounting professionals with accounting software backgrounds are categories of graduates likely to gain employment in current accounting practice.

From the findings, the research concludes that the incorporation of accounting software is not a threat to the accountancy profession (in terms of job losses and demotion) and that the role of accountants is still relevant in the business environment. However, stakeholders in the accountancy profession should be prepared and flexible to incorporate computerization. It is, thus, recommended that professional bodies such as ICAG and other business institutions should include accounting software education in their curriculum. This would help graduates of these accountancy bodies to be more relevant in the job market, which employers will increasingly be in search for in the future.

The study only considered professional accountants in Ghana, implying that the study findings cannot be generalized in the broader context of the entire working force in Ghana. Because of that, future studies should consider the impact of automation in every facet of the job market. 


\section{References}

Amanamah, R. B., Morrison, A. \& Asiedu, K. (2016), Computerized accounting systems usage by small and medium scale Enterprises in Kumasi Metropolis, Ghana. Research Journal of Finance and Accounting. $7(16)$

Birungi, A. (2000), The effectiveness of information technology in organisations. A case study of Post Bank

Burdick, C. (2010), Information systems and software applications. University of Phoenix.

Dabor, A., Aggreh, M. \& Aneru, M. (2016). Adoption of computerized accounting system by SMEs in Benin City. International Academic Journal of Economics. 3(1).

Daru, M. U. (2016), Role of accounting software in today scenario. International Journal of Research in Finance and Marketing. 6(6), pp. 25-34

Davis, S. (2015), What role does an accountant play in business operations? Retrieved from: http://smallbusiness.chron.com/role-accountant-play-business-operations-411.html

deSantis, J. (2010), A brief history of accounting: From prehistory to the information age. s.1.:http://ensign.ftlcomm.com/historyacc/researchpaperfin.htm

Ghasemi, M., Shafeiepour, V., Aslani, M. \& Barvayeh, E. (2011). The impact of information technology (IT) on modern accounting systems. Procedia-Social and Behavioural Sciences 28 (1), $112-116$

Hatcher, L. (1994). A Step-by-Step Approach to Using the SAS System for Factor Analysis and Structural Equation Modelling. SAS Institute, Inc., Cary.

https://accountsguy.net/tally/introduction-and-features/

Isiavwe, D. (2016), The role of accountants in modern business organizations. dtisiavwe@unionbankng.com

Kabir, M. R., Rahman, M. A., Yunus, M. \& Chowdhury, A. (2015), Applications of Accounting Software: An Empirical Study on the Private Universities of Bangladesh. World Review of Business Research. 5(1), pp.72-82

Kamyabi, Y. \& Devi, S. (2011), An Empirical Investigation of Accounting Outsourcing in Iranian SMEs: Transaction Cost Economics and Resource-Based Views. International Journal of Business and Management, 6(3)

Kothari, C. R. (2004), Research Methodology: Methods and Techniques. (3 ${ }^{\text {rd }}$ ed.). New Delhi, New Age International.

Krell, E. (2008), The crucial roles of professional accountants in business in mid-sized enterprises. International Federation of Accountants (IFAC)

Jui, L. \& Wong, J. (2017), Roles and importance of professional accountants in business. China Accounting Journal. 2(1).

Lim, F. P. C. (2013), Impact of Information Technology on Accounting Systems. Asia-pacific Journal of Multimedia Services Convergent with Art, Humanities, and Sociology, 3(2), pp. 93-106

Machera, R. P. \& Machera, P. C. (2017), Computerised accounting software: A curriculum that enhances an accounting programme. Universal Journal of Educational Research. 5(3).

Nagarajah, E. (2016). Hi, Robot. What does automation mean for the accounting profession? Accountants Today

Magloff, L. (2013), Advantage and disadvantages of computerized accounting. Retrieve from Smallbusiness.com:http://smallbusiness.chron.com/advantages-disadvantages-computerized-accounting4911.html

Mtetwa, M. (2010), Computerized accounting software system. s.1.:https://suite.io/munya-mtetwa/2wwj2fp.

Poston, J. (2014), Can Software Really Replace Accountants?

Ray, L. (2015). Strategic role of a chief accountant. Retrieved from: http://smallbusiness.chron.com/strategicrolechief-accountant-15963.html

Santos, J. R. A. (1999), Cronbach's Alpha: A tool for assessing the reliability of scales. Extension Journal, 37, 16.

Saunders M., Lewis P. \& Thornhill A. (2009), Research Methods for Business Students (5 ${ }^{\text {th }}$ ed.). Harlow, Pearson Education.

Shiraj, M. M. (2015). The impact of using computerized accounting systems (CAS) in financial reporting among SMEs: Special Reference to the South Eastern Region, Sri Lanka. 5th International Symposium $2015-$ IntSym 2015, SEUSL

Tijani, O. M. \& Mohammed, A. K. (2013), Computer-based accounting systems in small and medium enterprises: Empirical evidence from a Randomized Trial in Nigeria. Universal Journal of Management, l(1), pp.13-21

Yamane, T. (1967), Statistics, an introduction analysis. ( $2^{\text {nd }}$ Ed.). New York: Harper \& Row.

Zotorvie, J. S. T. (2016), Determinants of career choice among students of Institute of Chartered Accountants (Ghana). European Scientific Journal. 12(31) 